\title{
Firm Size, Business Experience and Export Intensity in SMEs: A Longitudinal Approach to Complex Relationships
}

\author{
Antonio Majocchi, Emanuele Bacchiocchi \\ and Ulrike Mayrhofer
}

\section{Introduction}

$\mathrm{T}$

The relationship between different variables such as size and age, and export performance has been studied intensively in recent years (Katsikeas, Leonidou, \& Morgan, 2000; Sousa, 2004). This trend can be explained by the process of globalization that has become an undisputed reality. Consequently, internationalization is not just an option that firms can choose to follow, but a sine qua non-condition for survival and success. Within the process of internationalization, export maintains a central role being regarded as the simplest and quickest way to access foreign markets. Given the relatively modest assets that export requires in terms of financial, managerial and organizational resources (Leonidou, 1995), it has always been considered as a practicable way into foreign markets for large but also for small and medium-sized enterprises (SMEs). Even if export seems a viable opportunity for all kind of firms, the relationship between export performance and size has long been disputed. In any case, export requires various organizational devices and resource commitments and, therefore, the results of export activities can vary significantly according to the availability of resources.

Therefore, it seems of particular relevance to investigate the relationship between sizes and export performance. Moreover, because of the striking changes that the process of globalization brought to international markets, findings of previous studies might not be valid anymore. A test of this relationship would allow verifying in how far the globalization process has modified the conclusions presented in previous research.

At the same time, firms require some specific knowledge to enter new foreign markets successfully. Therefore, many scholars (Davidson, 1980; Erramilli, 1991) suggest that experience is a crucial variable influencing a firm's ability to export.

Analyzing the main drivers behind export capacity is very important from at least two different perspectives. The first view considers export activities as a tool to achieve higher performance. According to this perspective, export success is a way to economic performance. However, this position has been challenged on the basis that the relationship between export and performance is not clearly established

Source: International Business Review, 14 (2005): 719-738. 
(Contractor, Kundu, \& Hsu, 2003). Some authors provide strong evidence for a positive relationship between the two variables (Jung, 1991; Kobrin, 1991), while others do not support this finding (Calof, 1994; Moen, 1999; Zucchella, 2001); some scholars have even proved a negative relationship (Geringer, Tallman, \& Olsen, 2000; Lu \& Beamish, 2001).

The second view sees export activities as an important step in the internationalisation process. Within the market entry strategy, exports represent a relevant stage that allows firms to gain international experience and to reduce uncertainty in foreign markets. According to this literature (Johanson \& Vahlne, 1977, 1990), the international expansion of firms is a learning process where firms progressively acquire international experience, leading them to increase their commitment to foreign markets (Forsgren, 2002). Export activities are regarded as a valuable means of internationalisation, because they allow firms to accumulate institutional, business and internationalisation knowledge (Sharma \& Blostermo, 2003). In fact, selling to foreign markets allows firms to become familiar with different national market rules (institutional knowledge), to get in contact with clients with different tastes and preferences (business knowledge) and to develop internal resources and routines dedicated to the servicing of international markets (internationalisation knowledge) (Majocchi \& Zucchella, 2003; De Chiara \& Minguzzi, 2002). From this perspective, exports are regarded as an optimal base for further internationalisation. According to this approach, the international expansion of firms can be regarded as a process where international activities develop incrementally over time (Bilkey \& Tesar, 1977; Ried, 1983). The accumulation of experience leads firms to a better knowledge of business opportunities both domestically and internationally and, therefore, as time passes the international involvement of firms increases.

Following this view, export is an effective way towards further internationalisation, but it requires time to acquire know-how and organisational capabilities in order to apply this knowledge for the effective export strategy. It thus seems relevant to test the relationship between experience and organizational capabilities, and export performance (as measured by export intensity).

According to this incremental approach, the authors of this article attempt to develop a dynamic approach to the debate on export determinants. Since the landmark work of Bonaccorsi (1992), most empirical studies dealing with the relationship between size and export intensity have adopted a cross-sectional method while a longitudinal approach is scarce (Leonidou, 2004). The cross-sectional methodology is certainly useful, but it does not consider the dynamic aspect of the internationalisation process. Export performance is not only volatile, but it also depends on past behaviour. As recently suggested by different authors (Clark \& Pugh, 2001), it would be particularly useful to combine the cross-sectional with a longitudinal approach. Based on a panel data, the empirical study presented in this article tries to fill this gap in the available empirical literature. The objective is to contribute to a better understanding of the relationship between firm sizes and export intensity and to evaluate, in this context, the role of experience. The first part of the paper reviews the extensive literature on the relationship between firm size and experience, and export performance measured through export intensity (export-to-total sales ratio) and develops the main hypothesis. The second part presents the methodology of the empirical research and the third part discusses the results obtained. 


\section{Conceptual Framework}

While the significance of export for firms remains an undisputed question, much more debate has been devoted to the problem of measurement and operationalization of export performance. Export performance is a multidimensional concept (Shoham, 1998) and many authors have offered different measurements of this variable. Recently, several papers have reviewed available empirical studies (Cavusgil \& Zou, 1994; Leonidou \& Katsikeas, 1996; Sousa, 2004; Zou \& Stan, 1998) and the number of recent reviews highlights the importance of the debate concerning this concept. Despite the large array of indicators, export performance measures can be placed in two different categories: (1) objective measures and (2) subjective measures. The first group refers to economic values such as sales related, profit related or market share related measures. They provide a directly comparable evaluation of performance (Shoham, Evangelista, \& Albaum, 2002). Sales and profit related indicators have the advantage of being objective measures while market share indicators have been criticized, because they are not really objective due to problems concerning the definition of market scope. As a consequence, these measures have seldom been used in empirical analysis. Subjective measures refer to indicators based on the managers' perception and satisfaction regarding export activities. These measures have been used in comparative studies (Woodcock, Beamish, \& Makino, 1994), when different accounting rules can lead to diverging practices in financial reporting, or in those cases when confidentiality can induce respondent managers to mask financial data on export.

In this research, given the data in hand, we exclusively rely on export intensity, i.e. the export-to-sales ratio. Even if this uni-variate measure has been subject to some criticism (Katsikeas, et al., 2000) we think that the measure remains useful on the basis of at least two main reasons. Firstly, this variable is, according to recent reviews (Katsikeas et al., 2000), by far the most widely used indicator in empirical research. This allows us to compare our results with a large number of similar studies. Secondly, being an objective measure, this indicator does not face the problem of manager resistance regarding confidentiality, which is a major issue when dealing with small and medium sized enterprises.

The relationship between firm size and export intensity has been one of the most controversial issues in the recent international business literature. Empirical findings appear to be contradictory: some scholars confirm a positive relationship between the two variables (Moini, 1995; Wagner, 1995), while others (Bonaccorsi, 1992; Moen, 1999) find no support for this hypothesis. Some authors even report a negative relationship (Patiblanda, 1995). Recently, Dhanaraj and Beamish (2003) have provided an exhaustive literature review of the debate on the determinants of export performance classifying the contributions on these themes according to the period and to the focus of the research. Their classification reveals that, in the 1970s, studies had mainly focused on the evolution of export performance, while in the 1980s, research was mainly based on empirical models. The last decade has been characterised by an increase of comparative studies and large sample research.

In the past, several studies have pointed out that empirical papers on export behaviour lack a solid theoretical framework (Cavusgil \& Zou, 1994). Several scholars 
have thus attempted to fill this gap. Their contributions are mainly based on two different views.

Some authors use a transaction cost approach (Verwaal \& Donkers, 2002). This approach highlights the importance of the governance structure that firms choose to develop in order to manage export relationships. Firms tend to prefer hierarchical 'mechanisms of governance, because (a) export relationships generally require a high level of specific investments dedicated to foreign markets and (b) the level of uncertainty appears to be higher in foreign markets. The establishment of these governance structures generate high fixed costs, which allow larger firms to capture economies of scale (Nooteboom, 1993) that cannot be reached by smaller firms. Expanding markets should help to spread common expenses over several countries (Tallman \& Li, 1996). The relationship between firm size and export intensity thus tends to be positive.

Other authors have adopted a resource-based view identifying intangible assets that define the competitive position of firms in export markets (Dhanaraj \& Beamish, 2003): the higher the resources the stronger the competitive position of the firm. According to this theory, firm resources can be classified into three different groups: (1) organisational resources, (2) entrepreneurial resources and (3) technological resources. The export literature has focused its attention on organisational resources (Leonidou, 1998); entrepreneurial and technological resources have rarely been considered as significant variables (Balabanis \& Katsikea, 2003; Dhanaraj \& Beamish, 2003). Organisational capabilities, often proxied by firm size, can be defined as non-imitable managerial abilities that, through organisational routines, transform financial and physical resources into competences that - in the words of Wernefelt (1984) - are 'partially analogous to entry barriers'. According to this view, the size of the firm should have an impact on export performance.

The two approaches mentioned are not incompatible. The positive relationship between size and export intensity can be explained either by the need to acquire dedicated resources devoted to foreign market entry activities or by the need to develop specific governance structures whose costs increase with internationalisation but can be better spread across different export activities.

All these models suggest that firm size does affect export intensity and that this effect decreases the larger the firm size. With regards to firm size, we decided to use the natural logarithm because it allows the measurement of relative changes in firm size. Analogous percentage changes in size are measured in a similar way, avoiding discrimination between large and small firms. Therefore, the following hypothesis can be developed:

Hypothesis 1a. Firm size is positively related to export intensity.

Hypothesis 1b. The relationship between the relative change in size and export intensity is non-linear and decreasing.

In both approaches, the transaction costs theory and the resource-based view, firms develop export activities either after building up specific governance structures or after developing dedicated resources. Satisfactory results in export markets can be achieved after firms have defined specific governance structures or created specific capabilities devoted to the foreign market. This explains the 


\section{Small Business Exporting: Adoption of Innovation}

positive relationship between size and export performance. With the notable exception of very large firms (Johanson \& Vahlne, 1990), that can shorten the process through the acquisition of specialised assets, the process of building dedicated resources is time consuming, especially for SMEs. SMEs lack the financial and managerial resources to rapidly acquire external services or specialised knowledge in order to follow the expansion path. As a consequence, for this type of firms, the accumulation of experience concerning both the management of international transactions and the market and cultural conditions of foreign countries appears to be a long process. Several scholars argue that the experience of a firm (organisational variable) affects its international position, with some authors concentrating only on international experience (Barkema, Bell, \& Pennings, 1996; Erramilli, 1991) and others on business experience, i.e. a firm's age (Balabanis \& Katsikea, 2003; Leonidou, 2000). The first type of experience, geographical experience (Ekeledo \& Sivakumar, 2003) refers to the firms familiarity with foreign market environments. The second kind of experience, industry experience, concerns the firm's familiarity with industry habits and rules regardless of the geographical location of clients and suppliers. It seems important to distinguish these two kinds of experience (Gomes-Casseres, 1989), because the effects on a firm's ability to export can be very different according to the company's strategy and to industry characteristics. For some firms, the need to adapt selling techniques to foreign markets, i.e. not only related to products but also to client relationships and habits, is low. Consequently, one of the main drivers of success in the market arena is industry experience. Other firms may have a totally different strategic approach to export due to sharp differences between market structures and consumer behaviour according to the geographical location of customers. For those firms, the international experience is an important determinant of export success. Firms must learn how to behave in a different market context and therefore the international experience is very important.

Since the selected database does not allow to discriminate between international experience and business experience, we rely on age as a proxy of business experience. Many authors have tested the hypothesis that learning and experience drive internationalisation (Chen \& Martin, 2001) and export performance (Balabanis \& Katsikea, 2003) with quite divergent empirical results. According to some scholars (Balabanis \& Katsikea, 2003), there is no evidence that age influences export performance and, along similar lines, all the recent born global literature (Madsen \& Servais, 1997; McDougall, Shane, \& Oviatt, 1994; Oviatt \& McDougall, 1994) sustains that time is no longer a crucial variable in defining the internationalisation level of firms. Born global firms are those that reach a high level of internationalisation 'from inception' according to the definition put forward by Oviatt and McDougall et al. (1994). For those firms, experience is not considered as an important variable for internationalisation. However, it must be noted that most of the literature on born global tends to concentrate on high-technology firms, mainly in service sectors, while our sample concerns manufacturing firms where the product still remains the main focus of the strategy. Therefore, the longer a firm remains in the market, the greater its knowledge about market relationships. Consequently, this knowledge can be employed in order to enter into new markets and attract new clients.

In contrast to many empirical studies, with the notable exception of Delios and Henisz (2003), we do not take age as a simple proxy of experience but we 
compute its natural logarithm. This decision is justified by the findings of certain authors (Leonidou, 2000; Welch \& Wiedersheim-Paul, 1980) who discover that newly established firms find more difficulties in overcoming export barriers due to a lack of organisational resources, managerial experience, and market and business knowledge. Dealing mainly with SMEs, we concede that what is really affecting export capabilities is not the absolute age of a firm but its relative change. One year's market experience might be insignificant in an old firm but could have a great importance for a two years old firm. Therefore, we relate export capability of firms to the log value of age and consequently we develop the following hypothesis:

Hypothesis 2. The relationship between export intensity and age of the firm is positive.

Finally, export performance is the result of a series of macroeconomic and industry factors such as the growth rate of demand in the domestic and in the export markets, the exchange rate variability and industry trends. These variables are not under the firms control but they may influence export performance. When available, we use these variables as control variables.

Figure 1 presents the conceptual framework for the study. The model explains export intensity in SMEs as a function of the interplay of firm specific and environmental factors. The paper focuses on the firm specific relationships, which are presented in the figure with a continuous line, with the expected sign of the

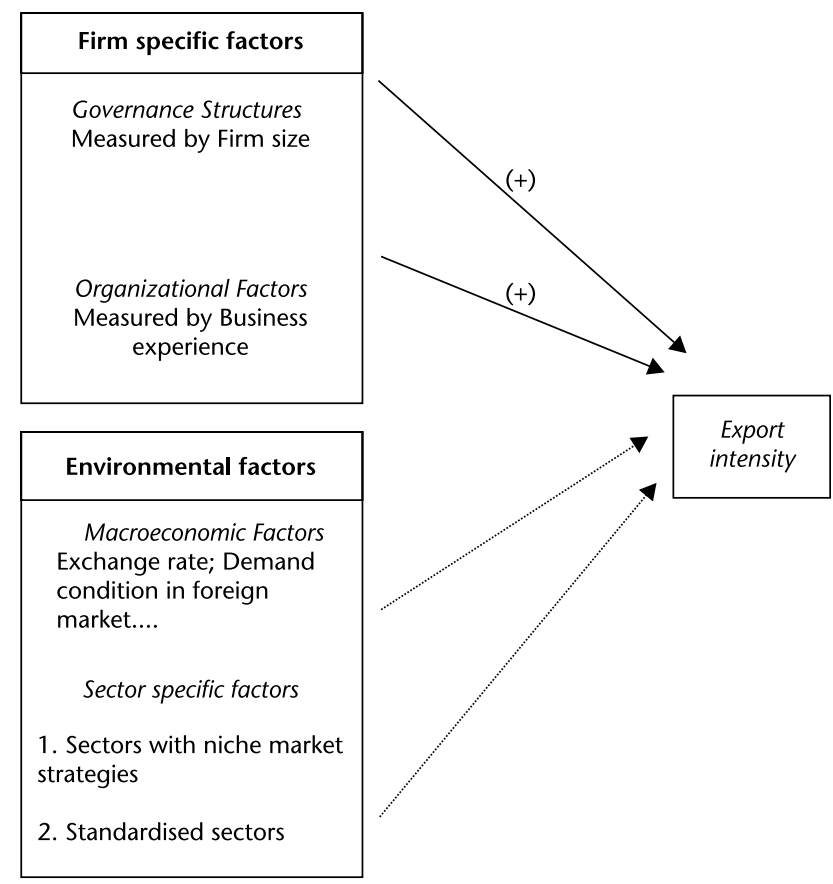

Figure 1: A general model of export intensity determinants (the paper tests the relationships presented with a continuous line). The expected sign of the relationship is presented within parenthesis 
relationship noted within parenthesis. The arrows with the dotted line represent the environmental factors (used as control variables), which can be either of macroeconomic nature or sector specific.

\section{Methodology}

The developed hypothesis will be tested on a sample of manufacturing firms. The sample has been taken from an official publication of a regional bank (Banca Regionale Europea, 2003) that reports the 5-year times-series financial reports of 144 manufacturing firms located in the North-Western part of Italy. These data has been extracted from a data set (Centrale dei Bilanci) that collects the balance sheets of firms financed by the Italian banking system. The dataset is managed by the Centrale dei Bilanci, a joint consortium formed by the Italian central bank and important Italian banks. This dataset has been used for scientific research (see i.e. Alworth \& Arachi, 2001; Varetto, 1998) due to its reliability. It is compiled from the official balance sheets that manufacturing firms have to submit to financial intermediaries in order to get credits. Firms have a strong incentive to deliver reliable data because the proportion of export out of total sales is a useful indicator of creditworthiness within the credit assessment process. Credit institutions can control the validity of this data because financial intermediaries channel all the foreign payments of the concerned firms. The information collected is therefore submitted to a double check: one by the credit institution that finances the firm and one by the consortium that holds records of the financial situation of all the Italian manufacturing firms versus the national banking system. As a result, the reliability of the data is strong.

The sample consists of 144 firms and balance sheets spanning the 1997-2001 period. The final sample comprises 142 cross-sections, after excluding two firms with missing data, and 5 years times-series that make up a total of 710 observations. Summary descriptive statistics of the sample are presented in Table 1.

Table 1: Descriptive statistics of the sample

\begin{tabular}{lcccr}
\hline Variable & Mean & SD & Min & Max \\
\hline Exp-intensity & 0.2002 & 0.2753 & 0 & 1 \\
Size (employees) & 137.1388 & 480.5082 & 1 & 5919 \\
Age & 26.23776 & 13.33314 & 3 & 83 \\
\hline
\end{tabular}

The sample mainly consists of small and medium-sized enterprises (SMEs, 92.4\%): $37.2 \%$ are small firms (less than 10 employees) and $55.2 \%$ are mediumsized firms (between 10 and 250 employees). This composition is representative of the general structure of Italian firms. In fact, according to official data (OECD, 1997), SMEs account for about $95 \%$ of the total number of Italian enterprises. It seems important to note that this percentage also reflects the European industry structure where the importance of SMEs is particularly high (European Commission, 2003).

In the developed model, the dependent variable is 'export intensity' and the independent (explanatory) variables are 'firm size' and 'firm age'. The model also includes a set of control variables. 
The estimated equation is as follows:

$$
\text { Exp_int }{ }_{i t}=\alpha_{1}+\alpha_{2} X_{i t}+\lambda_{\mathrm{i}}+\alpha_{3} \ln \left(e m p l_{i t}\right)+\alpha_{4}\left[\ln \left(e m p l_{i t}\right)\right]^{2} \alpha_{5} \theta_{\mathrm{i}}+\alpha_{6} \ln (\text { age })+\epsilon
$$

Exp_int $t_{i t}$ is the dependent variable defined as the ratio of export on sales, where $i$ denotes the firm and $t$ the temporal indicator.

$X_{i t}$ is a matrix of control variables that comprises the average exchange rate of the Euro against the extra-European currencies weighted according to the importance of the commercial partners (Euro), the yearly change of Italian domestic demand $\left(I_{-} D D\right)$ and the yearly change of domestic conditions on the French $\left(F_{-} D D\right)$ and German $\left(D_{-} D D\right)$ markets.

As explanatory variables, the model uses $\ln \left(e m p l_{i t}\right)$, i.e. the natural logarithm of the number of employees, its second order term $\left[\ln \left(e m p l_{i t}\right)\right]^{2}$, in order to measure the possible convexity effect in the relationship and the logarithm of age ( $\left.l_{-} A g e\right)$ as a measure of the firm's experience. Moreover, a dummy variable $\theta$ (dummy empl), which assumes value 1 for a firm with less than 20 employees and 0 for all the other firms, have been included in the equation in order to test for the presence of a threshold dimension under which the export intensity becomes irrelevant. ${ }^{1}$

Finally, we also consider the effects of industry specific factors introducing a set of industry dummies $\left(\lambda_{i}\right)$ where the number of the sector corresponds to the twodigit NACE classification used by the European Union. The coefficient of the sector dummies were computed against the food products and beverages sector (Nace classification no. 15) because this sector covers an important number of observations (180) and presents an average export intensity of $17.37 \%$, which is close to the overall export intensity (20.02\%). Therefore, the sector dummies coefficients should be interpreted in relation to this benchmark category. All other things being equal, a positive sign should be interpreted in the sense that firms in that sector have an average export intensity that is above the average of the food products and beverages sector of the sample.

Export intensity is a variable that shows a high level of volatility. This volatility can be attributed to the firm's export strategy, but also to environmental changes that influence export performance. Consequently, in a dynamic model, external factors (Balabanis \& Katsikea, 2003), such as opportunities and demand conditions that vary significantly from year to year, need to be taken into account. These factors may affect industry sectors in different ways, so in order to control for these effects, we have introduced some control variables.

Wagner (2001) convincingly argues that the relationship between firm size and export intensity should be studied with reference to specific industries. Therefore, we insert a set of industry dummies as control variables. The inclusion of industry effects in the model is particularly relevant with regard to small and mediumsized firms. While for large firms the definition of industry is often the result of a questionable choice due to the diversification strategies followed by this kind of firms, for smaller firms the industry definition is much more simple, given that these firms typically focus on a limited number of products.

Moreover, recent studies (Gomes-Casseres, 1997; Kohn, 1997) have highlighted the case of small firms that, through focusing on a niche market, have reached a high level of internationalisation. These firms tend to narrow the focus of their activities to a very limited segment so that they are small firms in absolute terms 
but not in relative terms when they are compared to their competitors. According to the literature, these firms tend to follow a specialised strategy developing a global approach in a very restricted segment. Firms thus succeed in gaining a leadership in these niches that are large enough for small firms but that do not have the depth that is necessary to attract the interest of larger firms. These segments are a sort of safe haven from large competitors for small and medium-sized enterprises. However, this kind of strategy is feasible only in those industries with a low level of standardization and with a large number of segments of different size. Typically, these segments are within sectors where customers are industrial buyers. The sectors therefore define the strategic alternatives available to firms. Unfortunately, our data does not allow us to test, beside industry effects, the possible effect that export strategies (Aaby \& Slater, 1989; Cavusgil \& Zou, 1994) may have on the results of export activities.

Available studies show that macroeconomic variables also influence the market selection process (Papadopoulos, Hongbin Chen, \& Thomas, 2002) and thus export performance. It seems relevant to consider the variation of demand conditions, i.e. the yearly change in consumption and investments in the domestic (Italian) market, in order to test if and how domestic market conditions (Madsen \& Servais, 1997; McNaughton, 2003) influence export performance. Furthermore, an index of economic conditions of the main foreign markets served by Italian firms, that is France and Germany, is introduced in order to test whether firms move to foreign markets when the economic conditions of these markets are positive. As a measure of economic performance, the yearly variation of domestic demand for France $\left(F \_D D\right)$ and Germany $\left(D_{-} D D\right)$, that cover almost $60 \%$ of Italian exports, is used.

Finally, following previous studies (Lu \& Beamish, 2001), we insert the level of the weighted exchange rate of the Euro against the basket of non-European currencies in the period in order to identify the possible effects of exchange rates on export intensity. The introduction of the weighted exchange rate of the Euro is justified by the fact that, during the observation period, exchange rates between European currencies had already been fixed with the only exception of the year 1997 when European rates were already converging. We, therefore, assume that exchange rates influenced only extra-European exports while intra-European commercial trade was not affected by exchange rate movements. At the same time, the price competitiveness of firms is highly dependent on the variation of exchange rates. We use the level of the Euro weighted by the relative importance of commercial partners with the Euro area. The idea behind the introduction of this variable is that an increase in the value of the Euro against other currencies should decrease the export competitiveness of European firms. A negative sign of the relationship is therefore expected.

The econometric methodology used for investigating the causality relationship between export ratio, firm size and experience consists of a linear regression in the context of a random effects panel data model (Baltagi, 2005). While the use of a panel data model is linked to the particular structure of the data, the choice of random effects rather than fixed effects might be questionable. Our choice can be justified by the fact that we empirically concentrate on the relation between export intensity, firm dimension and experience. Therefore, all excluded components need to be treated as random rather than as fixed, because they represent a sort of 'ignorance' on the part of the investigator about all other possible explanations of 
export intensity. Moreover, a Hausman misspecification test (Hausman, 1978) has been performed in order to control for the appropriateness of the random effect choice. The statistic, with 2 degrees of freedom, is 3.99 , with a related $p$-value of 0.18 . This confirms, that the null hypothesis of non-systematic difference in the coefficients estimated in fixed and random effect models cannot be rejected. The choice of a random effects panel model, however, does not exclude a priori the presence of individual features characterising each of the selected firms but emphasises that such individual features do not contribute to explaining the behaviour of firms in regard to export intensity. Moreover, sector dummies have been included in order to capture the fixed effects of sector structures on the export propensity of firms. In fact, such deterministic dummies could reveal the particular behaviour of certain sectors concerning export propensity, in so far that they might facilitate particular international connections and channels, which favour exports.

Even if the present analysis focuses on ratios rather than on levels of exports, which should exclude heteroskedasticity problems, a two step generalised least squares estimation procedure has also been performed as well as the OLS procedure reported below. All estimation results obtained for both magnitude and significance, however, do not appear substantially different.

Table 2 presents the correlation for the variables used in the empirical study.

Given the important level of economic integration, the correlation table indicates, as expected, a fairly high correlation between the economic performance of Germany and France, and Germany and Italy. In the general model, we consider all these variables before reducing them through a testing procedure in the restricted model. The reduction process aimed at obtaining a parsimonious model has been tested by a $\chi^{2}$ test, which confirms that the restrictions imposed are not strongly rejected by the data $\left(\chi^{2}(4)=1.07\right.$ with a $p$-value $\left.=0.90\right)$.

Table 2: Correlations

\begin{tabular}{lrrrrrr}
\hline & Expint & Empl & DD_F & DD_D & DD_I & Age \\
\hline Expint & & & & & & \\
Empl & 0.328 & & & & & \\
DD_F & -0.006 & 0.015 & & & & \\
DD_D & -0.012 & 0.002 & 0.667 & & & \\
DD_I & 0.029 & 0.013 & 0.054 & 0.453 & & \\
Age & 0.097 & 0.157 & -0.000 & -0.000 & 0.000 & \\
Euro & -0.051 & -0.017 & 0.127 & 0.193 & -0.654 & -0.000 \\
\hline
\end{tabular}

\section{Results and Discussion}

In order to test the hypothesis, two models have been run: (1) a general model that includes all variables and (2) a parsimonious model that results from a coherent reduction process.

The general model is presented in Table 3. It includes all the variables mentioned above. The general model shows that demand conditions both in the domestic and foreign markets are not significant. According to our analysis, export performance is not affected by the short-term economic trend. 


\section{Small Business Exporting: Adoption of Innovation}

Table 3: Parameters estimates and $t$ value and $p$-values (general model)

\begin{tabular}{lllcc}
\hline & Coefficient & Std. error & $t$-value & $t-$ prob \\
\hline Constant & 0.630980 & 0.7157 & 0.882 & 0.378 \\
I_empl & 0.177684 & 0.08346 & 2.13 & 0.034 \\
I_age & 0.0727749 & 0.03395 & 2.14 & 0.032 \\
Euro & -0.265856 & 0.1426 & -1.86 & 0.063 \\
I_dip2 & -0.00956552 & 0.008029 & -1.19 & 0.234 \\
DD_F & -0.811288 & 1.568 & -0.517 & 0.605 \\
DD_D & 0.924149 & 1.651 & 0.560 & 0.576 \\
DD_I & -1.63189 & 2.323 & -0.702 & 0.483 \\
Dum_empl & 0.0743450 & 0.06880 & 1.08 & 0.280 \\
S_17 & 0.0250903 & 0.09955 & 0.252 & 0.801 \\
S_18 & 0.0672253 & 0.1856 & 0.362 & 0.717 \\
S_19 & -0.287674 & 0.05246 & -5.48 & 0.000 \\
S_20 & -0.209346 & 0.06248 & -3.35 & 0.001 \\
S_21 & -0.103412 & 0.05516 & -1.87 & 0.061 \\
S_22 & -0.153371 & 0.07691 & -1.99 & 0.047 \\
S_24 & -0.0921187 & 0.1049 & -0.879 & 0.380 \\
S_25 & 0.0977856 & 0.08493 & 1.15 & 0.250 \\
S_26 & -0.122447 & 0.05678 & -2.16 & 0.031 \\
S_27 & -0.272215 & 0.05359 & -5.08 & 0.000 \\
S_28 & 0.0898934 & 0.08631 & 1.04 & 0.298 \\
S_29 & 0.183335 & 0.07494 & 2.45 & 0.015 \\
S_31 & -0.126436 & 0.06570 & -1.92 & 0.055 \\
S_33 & -0.101109 & 0.1292 & -0.783 & 0.434 \\
S_34 & 0.0424382 & 0.1112 & 0.382 & 0.703 \\
S_35 & -0.0625309 & 0.06542 & -0.956 & 0.340 \\
S_36 & 0.001337 & 0.09597 & 0.0139 & 0.989 \\
\hline SACE & 0 & 176 & \\
\hline
\end{tabular}

NACE statistical classification of economic activities: (17) Textiles; (18) Wearing apparel; (19) Tanning and dressing of leather and footwear; (20) Wood and of products of wood and cork, except furniture; (21) Pulp, paper and paper products; (22) Publishing, printing and recorded media; (24) Chemicals and chemical products; (25) Rubber and plastic products; (26) Other non-metallic mineral products; (27) Basic metals; (28) Fabricated metal products, except machinery and equipment; (29) Machinery and equipment; (30) Office machinery and computers; (31) Electrical machinery; (33) Manufacture of medical, precision and optical instruments; (34) Manufacture of motor vehicles; (35) Manufacture of other transport equipment; (36) Manufacture of furniture; manufacturing n.e.c.

sigma 0.23666, sigma ${ }^{2} 0.05600797 ; R^{2} 0.2895926, R^{2}$ adj $=0.264 ;$ RSS 38.309449991, TSS 53.926032604; no. of observations 710, no. of parameters 26; Wald (joint): $\mathrm{Chi}^{2}(8)=46.32$ [0.000]; Wald (dummy): $\mathrm{Chi}^{2}(18)$ $=206.2[0.0001 ; \operatorname{AR}(1)$ test: $N(0,1)=6.094[0.000] ; \operatorname{AR}(2)$ test: $N(0,1)=4.977[0.000]$.

The analysis of the consequences of the currency fluctuation (Euro) shows some interesting results. The effect of the exchange rate is, as expected, negative although the related coefficient is significant only at the $10 \%$ level. The negative sign of the coefficient of the Euro variable indicates that export performance tends to increase when the European currency devaluates with respect to other currencies and to decrease when the value of the Euro rises against other currencies. Our analysis confirms that this variable is a crucial one influencing the overall export position of the area. Especially for small firms, the chance to compensate currency movements with pricing policies is, in the short term, very limited. Therefore, any significant change in the relative position of the domestic currency tends, for those firms, to impact on the ratio of export on sales.

Also the squared value of firms size $\left[\ln \left(e m p l_{i t}\right)\right]^{2}$ is, according to out results, not significant suggesting that the simple linear relationship between size and export intensity is the most plausible one for the data at hand. Therefore hypothesis $1 \mathrm{~b}$ cannot be accepted. 
For both models, a Wald-type test has been performed to verify the significance of the entire regression and the significance of the sector dummies. As can be seen in Tables 3 and 4, all these tests support the significance of the linear relations considered. The results for the parsimonious model are shown in Table 4.

The model shows that the positive relationship between size and exportintensity is highly significant. Therefore hypothesis la is strongly supported by data. Following the study of Mittelstaedt, Harben, and Ward (2003) who found that a minimum size that firms must achieve in order to export successfully exists, we also test a possible threshold effect in our sample through the insertion of a dummy variable for firms with less than 20 employees. However, this dummy proves to be strongly insignificant: no structural change seems to be proved by our data for the smallest firms.

Clear results also come from the relationship between firm age and export performance. As expected, the relationship is positive and significant. Therefore, hypothesis 2 is supported: relative experience affects export performance and its impact is slightly lower than the one that has been computed for firm size.

Overall, the results seem significant from both a theoretical and a managerial point of view. From a theoretical point of view, the model strongly confirms that the relationship between firm size and export performance remains positive, even if the analysis is carried on over a 5-year period and not only on a cross-sectional basis.

Table 4: Parameters estimates and $t$ value and $p$-values of (restricted model)

\begin{tabular}{lclcc}
\hline & Coefficient & Std. error & $t$-value & $t$-prob \\
\hline Constant & -0.370686 & 0.1181 & -3.14 & 0.002 \\
I_empl & 0.0809460 & 0.01867 & 4.34 & 0.000 \\
I_age & 0.0750441 & 0.03362 & 2.23 & 0.026 \\
G17 & 0.0314391 & 0.09457 & 0.332 & 0.740 \\
G18 & 0.0755373 & 0.1830 & 0.413 & 0.680 \\
G19 & -0.276345 & 0.04587 & -6.02 & 0.000 \\
G20 & -0.200604 & 0.05666 & -3.54 & 0.000 \\
G21 & -0.100128 & 0.05009 & -2.00 & 0.046 \\
G22 & -0.143466 & 0.07514 & -1.91 & 0.057 \\
G24 & -0.0942061 & 0.1014 & -0.929 & 0.353 \\
G25 & 0.103388 & 0.08547 & 1.21 & 0.227 \\
G26 & -0.117891 & 0.05138 & -2.29 & 0.022 \\
G27 & -0.270017 & 0.04737 & -5.70 & 0.000 \\
G28 & 0.0975762 & 0.08307 & 1.17 & 0.241 \\
G29 & 0.189172 & 0.07129 & 2.65 & 0.008 \\
G31 & -0.118188 & 0.06296 & -1.88 & 0.061 \\
G33 & -0.0867456 & 0.1277 & -0.679 & 0.497 \\
G34 & 0.0547755 & 0.1093 & 0.501 & 0.617 \\
G35 & -0.0603886 & 0.06310 & -0.957 & 0.339 \\
G36 & 0.0139732 & 0.09302 & 0.150 & 0.881 \\
\hline
\end{tabular}

NACE statistical classification of economic activities: (17) Textiles; (18) Wearing apparel; (19) Tanning and dressing of leather and footwear; (20) Wood and of products of wood and cork, except furniture; (21) Pulp, paper and paper products; (22) Publishing, printing and recorded media; (24) Chemicals and chemical products; (25) Rubber and plastic products; (26) Other non-metallic mineral products; (27) Basic metals; (28) Fabricated metal products, except machinery and equipment; (29) Machinery and equipment; (30) Office machinery and computers; (31) Electrical machinery; (33) Manufacture of medical, precision and optical instruments; (34) Manufacture of motor vehicles; (35) Manufacture of other transport equipment; (36) Manufacture of furniture; manufacturing n.e.c. 


\section{Small Business Exporting: Adoption of Innovation}

In particular, in our restricted model, a $1 \%$ increase in firm size leads to an increase of $8 \%$ in export intensity. These results contrast the study of authors such as Bonaccorsi (1992) who, investigating Italian manufacturing firms, did not find any evidence concerning the relationship, or Kaynak and Kuan (1993) who even found a negative relationship. Madsen (1987) considered these contradicting results as the consequence of the limited explanatory power of organizational factors. In our point of view, it is the time period considered in the different studies that could explain these apparently contradictory results. Over the past decade, the importance of the relationships with clients has considerably increased. As several scholars have pointed out, maintaining and developing direct relationships with clients can provide, both in the consumer goods and in the industrial sectors, a competitive advantage (Doz, Santos, Williamson, 2001; Dwyer, Schurr, \& Oh, 1987; Heide \& Stump, 1995).

Consequently, firms that outsource foreign relationships appear to be less competitive and a tendency towards the internalisation of the management of transactions emerges. This general trend increases the organizational capabilities that firms must develop to address foreign markets. In order to export, businesses should create specialised functions that manage foreign orders, follow clients and monitor the evolution of non-domestic markets. This process generates fixed costs that lead to economies of scale. Firms need to increase in size in order to gain market shares in international markets and to better manage foreign clients. Therefore, our results tend to confirm the conclusions drawn by authors who hypothesised a positive relationship between size and export intensity. These results challenge the view that manufacturing firms can rely on external, but domestic resources in order to gain access to export markets. Networks and alliances can be a fruitful way to increase the firm's international competitiveness. However, if the firm does not build up specific resources dedicated to foreign market activities and to the management of these relationships, efforts to enter new markets seem to be fruitless because the monitoring of foreign transactions and the closeness of clients are becoming increasingly important. Firms thus prefer to internalise the management of foreign exchanges that cannot be subcontracted to other firms, but in order to do so, they need dedicated managers and carefully built structures. This interpretation seems to confirm the opinion of scholars such as Verwaal and Donkers (2002) who consider export intensity as the consequence of dedicated governance structures combined in order to effectively manage complex relationships. These results reinforce the view that a transaction cost approach to the study of export relationships is relevant. Managers can choose different alternatives, both internal and external, in order to monitor international transactions. Our results tend to confirm that the present conditions on international markets have pushed firms towards the internalisation path. This also means that export intensity is the result of managerial and organizational resources that have been developed through time as stressed by Dhanaraj and Beamish (2003).

Our second result is coherent with the view that confirms the positive relationship between export performance and relative experience. In their literature review, Zou and Stan (1998) note that a firm's age, expressed as the number of years in business, seems totally irrelevant to most of the studies or, if not, reducing export performance. On the contrary, our study indicates a positive and robust relationship, which can be considered as an innovative result. We attribute the 
originality of the results to the fact that we compute experience as a relative concept and not just as a measurement of firm life. With all the limitations due to the specificity of our sample, the point is not irrelevant and we think that it seems appropriate to further investigate the relationship.

The relationship between age and export performance is crucial in the sense that our results tend to confirm the idea that small firms need time to develop necessary experience of the market in order to export successfully. A fundamental part of this experience cannot be developed through international experience but just through incremental knowledge accumulated in the business arena. This conclusion seems coherent with the stage model theory that assumes that the Internationalisation process is based on a process of incremental knowledge through which firms reduce uncertainty. The model is essentially based on the idea that international experience is important; our conclusions also draw attention to the role of business experience. This aspect sheds new light on the emerging theme of international entrepreneurship. The growing literature (Kuemmerle, 2002) on this theme focuses attention on the level of export performance and mainly relates it to the years of existence of the firm. This kind of analysis is the consequence of the cross-sectional approach used in many studies. Based on a longitudinal approach, our analysis shows that this approach is limited and that it is not experience per se that counts but its marginal increase that matters. Small firms develop experience within business through personal contacts, networking activities, trials and errors. All the different experiences represent assets, which a firm can build upon. Once experience has been gained, it becomes a resource for the firm and in order to improve performance, it is only the relative change in this asset that really counts.

Considering the relevance of industry effects, as shown in Tables 3 and 4, we think that the topic deserves further comments. Our results show that these effects can be highly significant and that the distinction established in previous researches on export intensity between services and manufacturing sectors seems too broad and general. This item should be addressed much more carefully. Industry features define the environment within which firms operate. This is more true the smaller the firm's resources. Some authors (Zucchella, 2001) have verified that if environmental conditions allow for a deep segmentation of the sector, small firms can adapt themselves to niche markets that are small in terms of clients served and in terms of volume but that are geographically wide reaching. The strong results that we find in some sectors could be explained along these lines. We touch upon a point that has been neglected in previous studies and that should be further investigated. The results are mixed but nonetheless some hints for future research can be drawn out. Industry sectors such as machinery and equipment, where clients are typically industrial firms and where product differentiation strategies have been significantly pursued, show positive and statistically significant signs that testify to the structurally higher level of export intensity. These are the typical industries where global niche strategies are followed by small firms. In these sectors, firms can pursue product differentiation strategies that are effective even without the development of complex marketing and branding strategies that require considerable resources. However, we found a negative relationship for sectors that are typically characterised by a low level of product differentiation such as wood, paper, non-metallic products and basic 


\section{Small Business Exporting: Adoption of Innovation}

metal products sectors (sectors number, 20, 21, 26 and 27). For those industries, the relationship is negative and statistically significant. In those industries, small firms face more difficulties in carving out niches on a global scale and therefore the level of export performance is structurally lower.

\section{Conclusions}

The empirical analysis presented in this paper contributes to a better understanding of the relationship between firm size, market experience and export intensity. Concerning the relationship between firm size and export performance, the study provides a strong validation of the influence of firm size on export performance, on both cross-sectional and time-series basis. The fact that this relationship holds even if the analysis is longitudinal is, in our view, an important result. Export intensity appears to be a volatile variable, especially for SMEs where some unforeseen events like an unsolicited order or its sudden disappearance can abruptly increase or depress the level of export performance. Assuming a 5-year period we avoid this possible bias and we offer strong evidence in support of the relationship.

Moreover, our study confirms that, for manufacturing firms, industry experience is an important variable and that the relationship between age and export performance is positive. Firstly, our data shows that the relationship between age and export performance is not a linear one and that that it is the relative experience of firms that matters and not just age. These results can be explained referring to the need for firms to develop an international network of partners and customers. In order to set up this network, firms need time and information that, in the global information era, can be quickly developed. Once firms have gained access to this information and relationships, the main hurdles to international expansion have been overcome and, consequently, the effects of business experience are likely to decrease. This point should be taken into account within the lively debate on the born global phenomenon. In some way, our findings contradict the theory that the born global phenomenon is becoming important at least in the manufacturing industries, thus affirming that relative age still matters and that firms must accumulate knowledge. On the other hand, our results show that, for firms in the early stage of their life, a small increase in absolute experience has a great impact on export intensity and by this way supports the international new venture theory. The concept of relative experience needs to be developed and future research should concentrate on this analysis in order to generalise our re-sults both geographically and in terms of industries.

Moreover, it seems important to mention the impact of industry effects. Here, our results are mixed but nonetheless it appears that the common distinction between service and manufacturing sectors is too broad. Given the structure of the data used, we could rely only on the NACE classification of industrial activities. We think that a more detailed taxonomy of manufacturing industries, that groups sectors according to features such as technological and marketing intensity, scale economies and the distinction between industrial and final customers, is a promising line of research.

The empirical analysis has some limitations. Based on a sample of companies located in the North Western part of Italy, the analysis does not take into consideration 
the impact of geographical diversity on export performance, as suggested by Dhanaraj and Beamish (2003). Export intensity could be the result of different locational factors that are not considered in the present analysis but that could be important. Moreover, the constraint presented by the data set did not allow testing the influence of other determinants identified in the export-intensity literature such as technological intensity and internationalisation experience. The lack of an indicator measuring the international experience of firms needs to be taken into consideration. Since the pioneering work of Johanson and Vahlne (1977), the role of international experience has been widely tested in order to evaluate the effect of this variable on the internationalization process. A possible explanation of the significant effect of the relative experience variable could be due to the fact that most of this experience is in fact international. The very recent time period considered in our analysis makes this interpretation plausible. Unfortunately, data at hand does not allow us to test this hypothesis. We believe that further research on this point could be extremely fruitful.

Finally, given the significance of industry characteristics, a necessary complement to our analysis should be the inclusion of strategic variables such as the degree of diversification and differentiation or more specific marketing variables such as the intensity of export promotion activities, and the typology of export planning.

Despite these limitations, the empirical study developed in this article can be considered as a starting point for further research on the subject. It would be particularly appropriate to develop the obtained results on a larger scale and in different business environments and to further investigate industry effects.

\section{Note}

1. We thank an anonymous referee for raising this point.

\section{References}

Aaby, N. E., \& Slater, S. F. (1989). Management influences on export performance: A review of the empirical literature 1978-1988. International Marketing Review, 6(4), 7-26.

Alworth, J., \& Arachi, G. (2001). The effect of taxes on corporate financing decisions: Evidence from a panel of Italian firms. International Tax and Public Finance, 8, 353-376.

Balabanis, G. I., \& Katsikea, E. S. (2003). Being an entrepreneurial exporter: Does it pay? International Business Review, 12, 233-252.

Baltagi, H. B. (2005). Econometric analysis of panel data. England: Wiley.

Banca Regionale Europea, (2003). Economia e Finanza delle Imprese Manifatturiere Cuneesi. Banca Regionale Europea.

Barkema, H. G., Bell, J. H. J., \& Pennings, J. M. (1996). Foreign entry, cultural barriers, and learning. Strategic Management Journal, 17, 151-166.

Bilkey, W. J., \& Tesar, G. (1977). The export behaviour of smaller-sized Wisconsin manufacturing firms. Journal of International Business Studies, 8, 93-98.

Bonaccorsi, A. (1992). On the relationship between firm size and export intensity. Journal of International Business, 23, 605-635.

Calof, J. L. (1994). The relationship between size and export behaviour revisited. Journal of International Business Studies, 25, 367-398. 


\section{Small Business Exporting: Adoption of Innovation}

Cavusgil, S. T. \& Zou, S. (1994). Marketing strategy-performance relationship: An investigation of the empirical link in export market ventures. Journal of Marketing, $58,1-21$.

Chen, R., \& Martin, J. M. (2001). Foreign expansion of small firms: The impact of domestic alternatives and prior foreign business involvement. Journal of Business Venturing, 16, 557-574.

Clark, T., \& Pugh, D. S. (2001). Foreign country priorities in the internationalization process: A measure and an exploratory test on British firms. International Business Review, 10, 285-303.

Contractor, F. J., Kundu, S. K., \& Hsu, C.-C. (2003). A three stage theory of international expansion: The link between multinationality and performance in the service sector. Journal of International Business Studies, 34, 5-18.

Davidson, W. (1980). The location of foreign direct investment activity: Country characteristics and experience effects. Journal of International Business Studies, 11(2), 9-22.

De Chiara, A., \& Minguzzi, A. (2002). Success factors in SME's internationalization processes: An Italian investigation. Journal of Small Business Mangement, 40, 144-153.

Delios, A., \& Henisz, W. J. (2003). Political hazards, experience, and sequential entry strategies: The international expansion of Japanese firms, 1980-1998. Strategic Management Journal, 24(11), 1153-1164.

Dhanaraj, C., \& Beamish, P. W. (2003). A resource-based approach to the study of export performance. Journal of Small Business Management, 41, 242-261.

Doz, Y., Santos, J., \& Williamson, P. (2001). From global to metanational. How companies win in the knowledge economy. Boston: Harvard Business School Press.

Dwyer, F. R., Schurr, P. H., \& Oh, S. (1987). Developing buyer-seller relationships. Journal of Marketing, 51, 11-17.

Ekeledo, I., \& Sivakumar, K. (2003). International market entry mode strategies of manufacturing and service firms. International Marketing Review, 21, 68-101.

Erramilli, M. K. (1991). The experience factor in foreign market entry behaviour of service firms. Journal of International Business, 21, 479-501.

European Commission (2003). The observatory of European SMEs: SMEs statistics. Brussels: EU Commission.

Forsgren, M. (2002). The concept of learning in the Uppsala internationalization process model: A critical review. International Business Review, 11, 257-277.

Geringer, J. M., Tallman, S., \& Olsen, D. M. (2000). Product and international diversification among Japanese multinational firms. Strategic Management Journal, 21, $51-80$.

Gomes-Casseres, B. (1989). Ownership structures of foreign subsidiaries: Theory and evidence. Journal of Economic Behaviour and Organization, 11, 1-25.

Gomes-Casseres, B. (1997). Alliance strategies of small firms. Small Business Economics, 9(1), 33-44.

Hausman, J. A. (1978). Specification tests in econometrics. Econometrica, 46, 1251-1271.

Heide, J. B., \& Stump, R. L. (1995). Performance implications of buyer-supplier relationships in industrial markets. A transaction cost explanation. Journal of Business Research, $32,57-66$.

Johanson, J., \& Vahlne, J. E. (1977). The internationalisation process of the firm. A model of knowledge development and increasing market commitment. Journal of International Business, 8, 23-32.

Johanson, J., \& Vahlne, J. E. (1990). The mechanism of internationalisation. International Marketing Review, 7, 11-24.

Jung, Y. J. (1991). Multinationality and profitability. Journal of Business Research, 23(2), 179-187.

Katsikeas, C. S., Leonidou, L. C., \& Morgan, N. A. (2000). Firm-level export performance assessment: Review, evaluation and development. Journal of the Academy of Marketing Science, 28(4), 493-511. 
Kaynak, E., \& Kuan, W. K. (1993). Environment, strategy, structure and performance in the context of export activity. An empirical-study of Taiwanese manufacturing firms. Journal of Business Research, 27(1), 33-9.

Kobrin, S. J. (1991). An empirical analysis of the determinants of global integration. Strategic Management Journal, 12, 17-37.

Kohn, T. O. (1997). Small firms as international players. Small Business Economics, 9(1), $45-51$.

Kuemmerle, W. (2002). Home base and knowledge management in international ventures. Journal of Business Venturing, 17(2), 99-122.

Leonidou, L. C. (1995). Export barriers: Non-exporters' perceptions. International Marketing Review, 12, 4-25.

Leonidou, L. C. (1998). Organizational determinants of exporting: Conceptual, methodological and empirical insights. Management International Review, 38, 7-52.

Leonidou, L. C. (2000). Barriers to export management: An organizational and internationalization analysis. Journal of International Management, 6, 121-148.

Leonidou, L. C. (2004). An analysis of the barriers hindering small business export development. Journal of Small Business Management, 42(3), 279-302.

Leonidou, L. C., \& Katsikeas, C. S. (1996). The export development process: An integrative review of empirical models. Journal of International Business, 27, 517-551.

Lu, J. W., \& Beamish, P. W. (2001). The internationalization and performance of SMEs. Strategic Management Journal, 22, 565-586.

Madsen, T. K. (1987). Empirical export performance studies: A review of conceptualizations and findings. In S. T. Cavusgil, \& C. Axinn, Advances in international marketing (Vol. 2) (pp. 177-198). Greenwich, CT: JAI Press.

Madsen, T. K., \& Servais, P. (1997). The internationalisation of born globals: An evolutionary process? International Business Review, 6(6), 561-583.

Majocchi, A., \& Zucchella, A. (2003). Internationalization and performance: Findings from a set of Italian SMEs. International Small Business Journal, 21(3), 249-266.

McDougall, P. P., Shane, S., \& Oviatt, B. M. (1994). Explaining the formation of international new ventures. Journal of Business Venturing, 9, 469-487.

McNaughton, R. B. (2003). The number of export markets that a firms serves: Process model versus the born-global phenomenon. Journal of International Entrepreneurship, 1, 297-311.

Mittelstaedt, J. D., Harben, N. G., \& Ward, W. A. (2003). How small is too small? Firm size as a barrier to exporting from the United States. Journal of Small Business Management, 41(1), 68-84.

Moen, $\varnothing$. (1999). The relationship between firm, size, competitive advantages and export performance revisited. International Small Business Journal, 18, 53-72.

Moini, A. H. (1995). An inquiry into successful exporting. An empirical investigation using a 3 stage model. Journal of Small Business Management, 33(3), 9-25.

Nooteboom, B. (1993). Firm size effects on transaction cost economics. Small Business Economics, 5, 283-295.

OECD, (1997). Globalisation and small and medium enterprises (SMEs). Paris.

Oviatt, B. M., \& McDougall, P. P. (1994). Towards a theory of international new ventures. Journal of International Business, 24, 45-64.

Papadopoulos, N., Chen, H., \& Thomas, D. R. (2002). Toward a tradeoff model for international market selection. International Business Review, 11, 165-192.

Patiblanda, M. (1995). Firm size and export behaviour: An Indian case study. Journal of Development Studies, 31, 868-882.

Ried, S. D. (1983). Firm internationalisation, transaction costs and strategic choice. International Marketing Review, 1, 45-55.

Sharma, D., \& Deo \& Blostermo, A. (2003). The internationalisation process of born globals: A network view. International Business Review, 12, 753-793. 


\section{Small Business Exporting: Adoption of Innovation}

Shoham, A. (1998). Export performance: A conceptualization and empirical assessment. Journal of International Marketing, 6(3), 59-81.

Shoham, A., Evangelista, P., \& Albaum, G. (2002). Strategic firm type and export performance. International Marketing Review, 19(3), 236-258.

Sousa, C. M. P. (2004). Export performance measurement: An evaluation of the empirical research in the literature Academy of marketing science review, 2004, Vol. 9. Available: http://www.amsreview.org/articles/sousa09-2004.pdf.

Tallman, S., \& Li, J. T. (1996). Effect of international diversity and product diversity on the performance of multinational firms. Academy of Management Journal, 39, 179-196.

Varetto, F. (1998). Genetic algorithms in the analysis of insolvency risk. Journal of Banking and Finance, 22, 1421-1439.

Verwaal, E., \& Donkers, B. (2002). Firm size and export intensity: Solving an empirical puzzle. Journal of International Business Studies, 33, 603-613.

Wagner, J. (1995). Export, firms, size, and firm dynamics. Small Business Economics, 7, 29-39.

Wagner, J. (2001). A note on the firm size-export relationship. Small Business Economics, 17, 229-237.

Welch, L., \& Wiedersheim-Paul, F. (1980). Initial export: A marketing failure? Journal of Management Studies, October, 333-345.

Wernefelt, B. (1984). A resource-based view of the firm. Strategic Management Journal, $5,171-180$.

Woodcock, C. P., Beamish, P. W., \& Makino, S. (1994). Ownership-based entry mode strategies and international performance. Journal of International Business Studies, 25(2), 253-273.

Zou, S., \& Stan, S. (1998). The determinants of export performance: A review of the literature between 1987 and 1997. International Marketing Review, 15(5), 333-356.

Zucchella, A. (2001). The internationalization of SMEs: Alternative hypotheses and empirical survey. In M. Berry, M. McDermott, \& J. Taggart (Eds.), Multinational in a New Era (pp. 24-48). Palgrave: Basingstoke. 